\title{
Understanding How Public Finances Are Spent Under Devolved System of Government: A Case of Constituency Development Funded Projects in Kasipul Constituency, Kenya
}

\author{
Walter Otieno Andhoga (Corresponding author) \\ PhD Student, Department of Political Science and Peace Studies, Kisii University
}

Dr. George N. Mose

Lecturer, Faculty of Arts and Social Sciences, Kisii University

Dr. Johnson N. Mavole

Lecturer, Catholic University of Eastern Africa, Kenya

Received: Aug 7, 2018 Accepted: Aug 28, 2018 Online published: Sept. 5, 2018

doi:10.5296/jpag.v8i3.13611～URL: https://doi.org/10.5296/jpag.v8i3.13611

\begin{abstract}
Devolved system of government in Kenya was introduced in 2010, when a new constitution was promulgated. This drastically changed the way that public funds are allocated, spent and monitored by oversight institutions. Changes in governance structures envisaged devolution as a panacea that would ensure good governance, equity and transparency in the utilization of finances. The study used a case study of a devolved development fund that is implemented by the national government, the Constituency Development Fund (CDF) in Kasipul constituency, Homa-bay County to understand public finance management under devolved system of government. The study employed mixed methods research design involving both quantitative and qualitative data. A total of 400 respondents were sampled using multi staged proportionate random sampling techniques involving project beneficiaries, project managers, local governmental officials and the National Government Constituency Development Fund committee members. Data was collected using questionnaires, focus group discussions and interview guides. Quantitative data was analyzed using statistical techniques with the help of STATA version 14 . The study found that project financing had a statistically significant and
\end{abstract}


positive effect on the effective management of NG-CDF funded projects. The estimated coefficient of project financing in the model was found to be 1.436 with a statistically significant. It's therefore recommended that existing policies should be strengthened and a framework to improve the effectiveness of project management by increasing the levels of project financing. The existing financing model should be reformed to avoid the negative influence on the implementation of beneficiary projects to avoid systematic fund transfer delays.

Keywords: project finance, effective management, national government constituency development fund, structural equation modeling

\section{Introduction}

Decentralization has been promoted in the last couple of decades as part of governance reforms in a number of developing countries including Kenya. Globally, decentralization is credited as an institutional framework for equitable distribution of resources, improvement of service delivery such as health and education, and empowerment of local communities. (Bardhan 2002, World Bank, 2015). It is also recognized world over as an agent of good governance and democratization. As such decentralization is associated with a number of beneficial outcomes that have both direct and indirect impact at local and national levels of governance (Amponsah, 2012). Owusu et al. (2005) indicated that decentralization in Ghana has a positive impact on local government service delivery and strengthening of their mandate, there was still some shortcoming such as technical expertise capacity as well as good infrastructure. In both developed and developing countries, devolution is considered as an essential theme within the circle of governance (Dasgupta \& Beard, 2007). Devolved bodies have the capability to be easily accessed, monitored as well as watched therefore accountability and transparency in service delivery can be realized (Faguet \& Fabio, 2006). Accordong to (Chitere and Ireri, 2008), Decentralization in Kenya began with introduction of District Focus for Rural Development (DFRD) 1993. Therefore, devolution leads to good governance since it's an avenue of promoting suitable local representation and enhancing transparency in decision making. Globally, decentralization has been adopted especially in Africa, Asia and Latin America in countries where they have autocratic or military regimes as with aim of attaining democracy. Through democratization, decentralization has promoted good governance strategy thus achieving accountability, citizen participation, greater pluralism, transparency as well as development. Smith (2007) observes that decentralization is designed to reflect local unique circumstances in development policy-making and implementation accruing various benefits; making policies more responsive to local needs, provides a mechanism that is responsive to varying local circumstances thereby improving development allocations more efficient and makes local politicians and bureaucrats more responsive and accountable to local communities.

Decentralization in Kenya began with the introduction of District Focus for Rural Development (DFRD) 1993 by the Government as a strategy to further decentralized development interest using districts as key development units (Chitere \& Ireri, 2008). The involvement of parliamentary in community development as well as grassroots project raising 
in various set countries such India, Pakistan, Papua New Guinea, Jamaica, Uganda, Kenya among others as a form of decentralization (Mwangi \& Meagher, 2004). One of such policy tool is the Constituency Development Funds (CDFs) which main aim is to devote public funds for the purpose of benefiting a particular political sub division. The representative in the national parliament influences the allocation and in some cases the spending decision of CDF funds. The CDFs policy making entails size and goal of the funds, overseeing of CDF management and operations, the structure and modality on the utilization of CDF as well as the relative influence of various groups and individuals who are involved in the policy-making process that governance the utilization of CDF for social and economic developments.

The Constituency Development Fund in Kenya was established through NG - CDF Act 2003 and Amended in 2007 with other supplementary amendments in 2013 as well as 2016 whose main aim has been to adjust the administration of the fund with an aim of making it more project focus and constituents driven. The purpose of NG-CDF was to ensure there is equitable grass-root and constituency-level developments. The purpose of this devolved fund is to ensure there is rapid social and economic development by financing local prioritized projects at constituency level and improve public participation at community level (Owuor et al., 2012). Besides, the introduction of NG-CDF was aimed at controlling and reducing regional development imbalances as a result of partisan politics (Mapesa \& Kibua, 2006). There have been doubts on whether CDF has achieved its objective from various quarters giving an obvious signal that the degree to which NG-CDF has achieved set goals continues to research imperative domain for scholars (Bagaka, 2008).

A report by the KTPA for $2014 / 15$ revealed that $40 \%$ of the NG-CDF remained accounted for, $20 \%$ of the projects were not successfully completed, only $5 \%$ were successfully completed, and over 35\% had been well utilized. The CDF amendment Act (2015) provides guidelines on fund management in term of allocation, re-allocation, disbursement and unspent fund. However, there are various irregularities that have been associated with financial resources raising serious governance issue from Auditor General Office and civil society. It is not clear how project financing impacts successful implementation of NG-CDF developed projects. The general objective of this study was to investigate the influence of projects financing on effective management of National Government Constituency Development Funded projects in Kasipul constituency, Homa Bay County, Kenya. The study is limited to evaluating the effective management of National Government Constituency.

\section{Theoretical and Empirical Literature}

This study is guided by resource-based as well as agency relationship theory. The resource-based view of the firm (RBV) explains that each institution or organization has unique resources and capabilities that make them different hence the competitive advantage (Muthuuri, 2014). The main tenet of the theory is organization capabilities and resources vary from one firm to another and this difference in variation can aid a firm to attain stability (Hijzen, Görg \& Hine, 2005). The theory recognizes human resource competence, financial resources and past experiences as organization critical success (Hamel \& Prahalad, 1996). 


\section{Mll Macrothink}

Journal of Public Administration and Governance

ISSN 2161-7104

2018, Vol. 8, No. 3

The performance of an organization depends on how resources and capabilities are mixed as well as the manner of deployment.

The principal and agent theory assumes that both the principal and the agent are motivated by self-interest. This assumption of self-interest dooms agency theory to inevitable inherent conflicts. Thus, if both parties are motivated by self-interest, agents are likely to pursue self-interested objectives that deviate and even conflict with the goals of the principal. Yet, agents are supposed to act in the sole interest of their principals (Paul et al., 2013). In agency relationships the agent has a moral responsibility for his/her actions, which may not be dismissed simply because one acts as an agent for another (Waal, 2004). As far as the theory is concerned one of the parties is better informed than the other, and in which parties do not share the same interests, it is likely to have a growing influence on effective project management, where project parties bring together a wide variety of both expertise and interests to the task at hand. The principal-agent theory offers a useful representation of project management as applied to CDF funded projects and other fields in which project management plays an important role.

Project completion theory on the other hand according to Nutt (1996) is considered as various steps taken serially by reliable agents of an organization to scheme change process so as to stimulate compliance required for installation of changes. Project managers utilize project completion theory so as to make organization achieve planned changes through creation of environments in which changes can persist (Slevin and Pinto, 1987). The realization of successful implemented project depends on the project manager capabilities in terms of energy and time on financial, technical and human resources. Project completion theory underscores various critical success factors during project management. They include top management support and project schedule plan. Top management support for project or any kind of implementation determines success or failure of a project (Schultz \& Slevin, 1975). However, Beck (1993) revealed that the success of project management does not wholly depend on top management support, direction and authority but more importantly the manners in which top management set organization goals as well as implementing plan. Schedule plan involves coming up with a comprehensive plan that is needed for all implementation process stages.

Project management is critical as it allows monitoring of project progress which can be realized through financial process of soliciting and maintaining sufficient finances for project activities (Gasper, 1999). Adequacy of funds is crucial for effective implementation of projects to be realized. Jack and Samuel (2006) cited inadequacy of funds as the main resources for poor project outcomes such as delay in completion and unexpected poor standards. Natasha (2003) commitment of financial resources as well as other resources to project management especially from the benefiting communities is crucial for successful project completion. Financial Resources allocation is essential to all successful project management. Good financial governance is imperative in any public project as it enhances accountability and transparency. According to African Financial Governance Status Report (2011) prudent financial governance ensures there efficient and effective use of resources as well as sound fiscal management. It can be concluded that to ensure an organization attains 
maximum level of accountability and transparency in the utilization of organization financial resources and long term success both economically and socially, there is need to employ financial governance systems which are efficient and effective in the use of resources. Pretorius and Pretorius (2008) asserted that various recent literatures underlined the significance of prudent financial governance through adoption of firm systems of financial management to poverty reduction and service delivery so as to attain sustainable development goals. The execution of budget is the stage in which resources of organization are utilized so as to implement various activities within the organization. During budget execution, focus is usually directed so as to comply with budgetary authorizations and this is subject to internal control system governance. Mensah et al. (2003) faulted vulnerable internal control systems as recipe for financial misappropriation through side deals to influence contracts or making of unapproved side payments. In effort to ensure that there are stringent internal control systems for good governance, there must be provisions explain the roles of the management, financial accounting and payment which associate with budget execution.

Empirical evidence have supported the notion that financial resources management through the process of budget execution has strong relationship with governance of projects. Using US organizations, Elbannan (2009) revealed that quality internal controls has positive relationship with good governance. Further, Jensen (1993) indicated that board governance efficiency is positively related to the effectiveness of internal control. It can therefore be deduced that good governance is dependent on internal control system strength in regard to project execution. One of the most crucial causes of delay in Malaysian construction sector according to Sambasivan and Soon (2007) is inadequate client's finance. Haseeb et al.'s (2011) study further stated that, financial problems are major delay factors in Pakistani construction industry. Khalied and Amr (2009) postulated that infrastructure projects require vast initial capital outlay and are usually developed so as to be operated over a relatively long duration.

Investigating the influence of financial resources on the implementation of small project ventures in the cottage industry in India, Jamal (2004) indicated that Indian's cottage projects started with the production of simple household items, but have improved over time surprising the traditional industrial nations of the world with popular industrial products. He observed that, this great milestone achieved in the growth of cottage industry in India was facilitated by the government's interest in allocating funds to the industry as it was creating job opportunities to the citizens. In Trinidad and Tobago in the West Indies Islands, Mijean (2007), noted that productivity of an enterprise was a direct consequence of availability resources. He further enumerated the resource types that influence business success as, fixed assets, operating cash and skilled personnel. Sullivan and Mayer (2010) indicated that the most consistent greatest hindrance to timely delivery of project is budget limitations. According to them, it is difficult to compensate inadequacies of funds unlike other limitations such as technical or human capacity which can the compensated through outsourcing and training. Therefore, according to Gwadoya (2012), financial resources should be realistically planned and estimated in advance before commencement of projects especially building and construction projects. There is a need to plan financial resources for various project functions 
separately so as to avoid run off during the execution of projects. This can be achieved by having two distinct budget lines for actual project implementation and another one of project management through monitoring and evaluation.

In Africa, project management approach is considered the most effective technique for turning around the performance of all sectors of development. Based on factors influencing implementation of community-based poultry projects in Guinea Bissau, Tounde (2012) noted that effective project implementation is a field of practice that demands skilled personnel, yet most project participants did not display substantial ability to effectively perform their individual project activities. In Ghana, implementation of health projects was hampered due acute cash flow problems in the district hospitals. It was noted, there was delay in cash disbursement which disrupted the construction of health unit (Asante et al. 2006). Kikwasi (2012) in Tanzania, there are se are serious disruptions and delay facing government funded construction projects. Some of the causes of these delays included funding problems, compensation issue, work valuation disagreement and contractors' payment delays. Gwaya et al. (2014) noted that, project financing was one of the key client's obligations. It is asserted that, delays and cost overruns in public sector investments can raise the capital-output ratio in the sector and elsewhere thus bringing down the efficacy of the investment. Shamala (2006) conducted a study on factors influencing viability of brick making projects in Busia County that bricks remained the most popular building material in Kenya, yet lack of resources to transport those products to competitive markets exposed them to exploitation by the brokers whose prices were poor. In Bomet County, Chepkorir (2010) established that due to lack of financial resources to put up green shades for selling agricultural products such as green maize, fruits, vegetables and Irish potatoes, sellers resorted to lining directly along the road. Moenga, (2015) posits that the most important factor influencing timely completion of construction projects in Kenya is; financed by the contractor during the project and delays in contractor's payment. Kalungu (2010) indicated that to achieve the objectives and goals set by the government in allocation of CDF resources proper budgeting practices for the resources should be put in place to aid in planning, coordinating and control of the resources. The study found out that activity based budgeting was preferred by many constituencies, while a few practiced a combination of activity based and zero based budgeting. The respondents cited some challenges to the budgetary preparation as lack of enough time for budgeting, lack of clear budgeting policies to budget the funds, lack of enough trained personnel on financial management and lack of access of CDF information for all and lack of budget committees. This could be addressed if these factors were put in place in order to enable proper utilization of $\mathrm{CDF}$ resources in Kenya for the common benefit of the local citizens. A descriptive survey study carried out in Kimilili Constituency by Kibebe and Mwirigi (2014) on the selected factor affecting CDF projects implementation. The study targeted 103 respondents who have benefitted from CDF projects and they were selected using systematic sampling, purposive sampling, and proportionate sampling and stratified sampling design. Data collected from questionnaires revealed that there was significant relationship between CDF projects implementation and managerial factors such as knowledge, skills and staff competence. However, in a qualitative cross-sectional study to investigate financial performance of water projects in Kenya funded by CDF, the findings from interview 
conducted on project managers revealed that fund management practices such use of budgetary allocation has significant strong positive influence on the financial performance (Kung'u, \& Mwangi, 2014). In conclusion, NG - CDF Project financing has been pointed as a significant tool towards project implementation. The suggested indicators include Availability (Gasper, 1999; Natasha, 2003), Disbursement (Jack and Samuel, 2006) and Allocation of resources (Kikwasi, 2012).

\section{Research Methodology}

This study adopted mixed method research design to examine the effectiveness of NG - CDF management in Kasipul constituency. It drew liberally from both quantitative and qualitative assumptions. According to Creswell, (2003) the research problem, personal experiences of the researcher, and the audience(s) for whom the report will be written play as key role behind the decision of the research design. This design is useful this research design was suitable since; first, the researcher was interested to both generalize the findings to a target population and develop a detailed view of the meaning of all study aspects with regard to effective management of the NG-CDF funded projects. Kasipul Constituency, one of the constituencies in Homa Bay County comprises of five wards; West Kamagak, West Kasipul, East Kamagak, South Kasipul and Central Kasipul. According to Kenya National Bureau of Statistics 2013 for Homa Bay County, the population for Kasipul was projected to be 183,073 in the year 2015 with a population density of $525 \mathrm{KM} 2$. Poverty rate in the constituency is $49.4 \%$. The poverty index is higher than national average of $47 \%$. According to project implementation status report as at May 2016, some of the projects that started 2013/2014 had not been completed. The delay in completion of these projects and need for extra resources for their completion is the basis of the study. The general completion rates at the moment stands at 42.9\% of NG-CDF projects funded between 2013/2014 and 2015/2016, rate below the minimum expectation according to Kenya Tax Payers Association (KTPA).

The study targeted 254 projects in the Kasipul Constituency between 2013/2014 and $2015 / 2016$ in the five wards. The projects were categorized as education, health, water, security, roads, sports and environment. According to Kenya National Bureau of Statistics (2013) the population for Kasipul Constituency was projected to be 183,073 in the year 2015. These projects formed the unit of inquiry from which three beneficiaries were selected. The study therefore targeted 183,073 possible beneficiaries, 254 project managers, 10 NG-Constituency development fund committee and 7 government representatives (departmental Heads from the respective represented sectors). Quantitative and qualitative approaches (mixed methods) guided data collection procedures were employed in this study. Tools including questionnaires, focused group discussions schedules and interview guides were used to collect primary data on the determinants of effective CDF projects management in Kasipul Constituency. From these universe populations, samples were drawn to collect relevant data for this study.

A pre-field survey was conducted by the researcher to ascertain on some parameters during the proposal writing process in Kasipul Constituency. These parameters included: - Projects executed by the constituency administration within the study period, the type of projects done, 


\section{Macrothink}

the budget allocated. Informed by this pre-field study, this study sampled 77 NG-CDF projects from 254 projects. The sample size for the projects in this study was selected based on the criteria set by Roscoe's rule of thumb Sekaran (2003) i.e. a sample that is larger than 30 and less that 500 is appropriate for most research. Also according to Mugenda \& Mugenda (2008) a sample size of between $10 \%$ and $30 \%$ is a good representation of the target population while according to Dooley (2007), a sample size of between $10 \%$ and $40 \%$ is considered adequate for detailed or in-depth studies hence the $30.31 \%$ of the NG-CDF projects was adequate for analysis. The sample size of 77 NG-CDF projects was obtained using coefficient of variation. Nassiuma (2000) asserts that in most surveys or experiments, a coefficient of variation in the range of $21 \%$ to $30 \%$ and a standard error in the range of $2 \%$ to $5 \%$ is usually acceptable.

$$
S=\frac{N(C v)^{2}}{(C v)^{2}+(N-1) e^{2}}
$$

Where $S=$ the sample size

$$
\begin{aligned}
& \mathrm{N}=\text { the population size } \\
& \mathrm{Cv}=\text { the Coefficient of Variation } \\
& \mathrm{e}=\text { standard error }
\end{aligned}
$$

Therefore, the sample size was:

$$
\begin{aligned}
& \mathrm{S}=\underline{254(0.212)} \quad=76.87989019 \approx 77 \mathrm{NG-CDF} \text { Projects } \\
& \{0.212+(254-1) 0.022\}
\end{aligned}
$$

Further, the researcher adopted Yamane, (1967) formula that can be used to calculate a suitable sample for the study which comprised of all NG-CDF beneficiaries currently in the Wards.

$$
n=\frac{N}{1+N e^{2}}
$$

Where $\mathrm{n}=$ Minimum Sample Size; $\mathrm{N}=$ population size: $-\mathrm{e}=$ precision set at $95 \%$ $(5 \%=0.05)$ 183,073 (Study population) x0.5 =

$$
\begin{gathered}
\mathrm{n}=183,073 \\
1+183,073(0.0025) \\
\mathrm{n}=399.11 \approx 400 \text { Beneficiaries. }
\end{gathered}
$$

The projected sample size for the beneficiaries were 400 respondents from the $77 \mathrm{CDF}$ projects, all the $10 \mathrm{NG}$ - CDF committee members of Kasipul Constituency, 77 Contractors/project managers awarded contracts between 2013/2014 and 2015/2016 and 7 government representatives (departmental Heads). The researcher applied multi-stage sampling technique to select the 400 beneficiaries of $77 \mathrm{CDF}$ projects. Initially, the researcher used proportionate sampling technique to get proportionate number of projects from each 
ward in the constituency. Then the researcher formed focused group discussions to get important information that needs clarification from the constituents. According to the Kenya national government constituencies Development Fund Act 2015, NG - CDF committee at the constituency level should have 10 members. These 10 members represent general interests of the Constituency. The researcher used census sampling technique of all the $10 \mathrm{NG}$ - CDF committee members to form part of the sample of interest to the study. The researcher targeted to interview the committee members from each of the NG-CDF projects sampled, contractors/project managers and government heads departments who also formed part of the sample of this study.

Quantitative and qualitative approaches (mixed methods) data collection procedures were employed in this study. Tools including questionnaires, focused group discussions schedules and interview guides were used to collect relevant data on the role of project financing on effective CDF projects management in Kasipul Constituency. Primary data was collected by use of questionnaires and interview guides while secondary was obtained from CDF project records. Further, primary data was obtained from the focused group discussions constituted of the beneficiaries.

To enhance reliability, the researcher prepared questionnaires and interview guides and administer them to the similar respondents' in Kasipul Constituency for pre-testing purposes. These respondents were however not used in the main study. Approximately 15 participants were used for pilot study. This is according to Isaac and Michael (1995) who suggested $10-$ 30 participants is ideal in pilot study.

To measure the reliability, the Alpha (Cronbach) technique was employed. Alpha (Cronbach) is a model of internal consistency, based on the average inter-item correlation. A large value of alpha (preferably greater than 0.7 ) indicates high level of consistence of the instruments in measuring the variables. Kline (1999) noted that acceptable value for Cronbach's alpha is between 0.7 and 0.9 of which this study adopts.

On the other hand, validity focused on how well a concept, idea, or behavior that is a construct has been translated or transformed into a functioning and operating reality (Aila \& Ombok, 2015). This study assessed validity of the study instrument using construct validity. For this study, construct validity which seeks to measure whether an instrument accurately measures the study phenomena was tested using factor analysis then confirmatory factor analysis to verify the construct validity, this is recommended for large sample techniques $(n>50)$ (Aila \& Ombok, 2015). The study uses 15 respondents in pilot study to ascertain validity. In addition, since all the respondents are relatively homogenous in terms of socio-culture and socio-economic, the results can be generalized to the entire population of the study.

The relationship between Project Financing and dependent variables was measured using Structural Equation Modeling (SEM) which is best suited to analyze paths for latent variables. This informs whether the project financing significantly influences effective implementation of projects in Kasipul Constituency and thereby test the research hypotheses. 
SEM provides a more parsimonious representation of the constructs and a better way to account for the individual contribution of each item by more precisely modeling measurement error (Bollen, 1989). Respondents' responses to five items that measured project financing latent factor derived from availability, disbursement and allocation of project financing. The model fitted was defined by the equation below;

$$
y=\beta_{1} X_{1}+\varepsilon
$$

Where;

$\mathrm{Y}=$ Effectiveness of NG - CDF project management, $\beta_{1}=$ Regression Coefficient of $X_{1}, X_{1}=$ Project financing.

The structural equation model was fitted using Analysis of moment structures (AMOS) software version 23. All ethical considerations were considered. For confidentiality, the identity and privacy of the respondents was protected by the researcher. No pressure or inducements of any kind was applied to encourage the respondents to become participants in the research study.

\section{Results and Discussions}

Considering the instrument return rate, out of the 400 of the questionnaires distributed to NG-CDF beneficiaries the researcher was able to collect 321 questionnaires representing $80.25 \%$ and out of 77 distributed to NG-CDF contractors and project managers, the researcher was able to collect 71 back representing 92.2\%. Out of the 10 questionnaires distributed to NG-CDF committee members all the questionnaires were returned giving a return rate of $100 \%$. Generally, the return rate was high and able to answer the set objectives of the study. Mugenda and Mugenda (2003) assert that a response rate of more than $50 \%$ is adequate for analysis. Babbie (2004) also asserts that a $60 \%$ return rate is good and a $70 \%$ return rate is very good. Project financing is essential to all successful project management.

Good financial governance is imperative in any public project as it enhances accountability and transparency therefore improves public trust. Project financing was measured using adequacy allocation to projects, timely disbursement of the funds, auditing process, transparency and accountability. Five statements were formulated to measure the project financing using a five point Likert-type scale ranging from $1=$ strongly disagree to $5=$ strongly agree and respondents were asked to indicate the extent to which they agreed to the statements. They included; accountability and transparency in the use of CDF fund for the management of projects, satisfaction level with the auditing process of NG-CDF projects, timely disbursement of CDF finances to the identified projects, sufficiency of the funds as per the various projects in the constituency, adequate allocation of the funds to the various projects. The section analyzes the views of beneficiaries, project managers/contractors and NG-CDF constituency committee on the project financing of the of NG-CDF projects in Kasipul Constituency. Table 1 presents findings as obtained from beneficiaries of CDF projects in Kasipul Constituency. 
Table 1. Project Financing - Beneficiaries

\begin{tabular}{ccccc}
\hline Project Financing & Modal class & Median & Mean & STD \\
\hline Accountability and transparency & 3 & 3 & 3.12 & 1.13 \\
Auditing process & 2 & 2 & 2.81 & 1.29 \\
Timely disbursement & 4 & 4 & 3.48 & 1.19 \\
Funds allocation & 3 & 3 & 3.00 & 1.15 \\
Adequate allocation & 4 & 4 & 3.38 & 1.19 \\
Overall Mean & $\mathbf{3 . 2}$ & $\mathbf{3 . 2}$ & $\mathbf{3 . 1 6}$ & $\mathbf{1 . 1 9}$ \\
\hline
\end{tabular}

Source: Field Data (2017)

From Table 1, The question as to whether there is accountability and transparency in the use of CDF fund for the management of projects, the modal class and median were both 3 and the mean was 3.12 with a standard deviation of 1.13 . This shows that on average of the respondents are not sure as to whether there is accountability and transparency in the use of CDF fund for the management of projects. As portrayed by the modal class of 2 an median of 2 , on average, the respondents are in disagreement with the statement on satisfactory auditing process of NG - CDF projects. The modal class and median both being 4 for timely disbursement portray that the average response was of agreement that there is timely disbursement to the identified projects which has enhanced project management. However, the responding beneficiaries on average showed indecisiveness as to whether there is sufficient funds allocated for various aspect of CDF projects with a mode and median of 3. Further, the sampled respondents showed that on average the beneficiaries agree that CDF funds are adequately allocated to the identified projects as shown by the median and mode which are both equal to 4 . The overall mean response was 3.16 , which implied that the sampled respondents were undecided on most of the statement regarding project financing while a standard deviation of 1.19 denoted that there was some variation the response on the statement on project financing from beneficiaries' point of view. This finding showed that there was evidence of disagreement in various constructs that was used to determine project financing effectiveness and in some cases the respondents were not sure on funds allocation, transparency and accountability.

Table 2. Project financing-Project Managers/ Contractors

\begin{tabular}{lcccc}
\hline Project Financing & Modal class & Median & Mean & STD \\
\hline Accountability and transparency & 4 & 4 & 4.13 & 1.05 \\
Auditing process & 4 & 4 & 4.00 & 1.13 \\
Timely disbursement & 2 & 4 & 3.32 & 1.38 \\
Funds allocation & 2 & 3 & 3.20 & 1.26 \\
Adequate allocation & 2 & 3 & 3.27 & 1.26 \\
Overall Mean & $\mathbf{2 . 8}$ & $\mathbf{3 . 6}$ & $\mathbf{3 . 5 8}$ & $\mathbf{1 . 2 2}$ \\
\hline
\end{tabular}

Source: Field Data (2017)

From Table 2, the sampled project managers/contractors on average confirmed that there is accountability and transparency in the use of CDF fund for various projects as shown by the mode and median that are both equal to 4. Similarly, there was an average agreement amongst the sampled project managers/contractors of satisfaction with the auditing process of $\mathrm{NG}-\mathrm{CDF}$ projects as indicated by all measures of central tendency equaling 4 . The results 
further revealed that the CDF project managers/contractors confirmed that on average CDF funds are timely disbursed to the identified projects which have enhanced project management with a median of 4 . As shown by the mode of 2 , majority of the sampled project manager/contractors disagreed that there are sufficient funds allocated for various aspect of CDF projects which has resulted to effective management of CDF. Using the median of 3 as the average however shows that the respondents were undecided regarding sufficient fund allocation. as compared to $28.2 \%$ agreed and $19.7 \%$ strongly agree with a mean of 3.20 and standard deviation of 1.26. Majority as per the mode of 2 also disagreed with the allocation adequacy however, the median of 3 showed that on average the respondents were undecided as to whether $\mathrm{CDF}$ funds are adequately allocated to the identified projects which has enhanced project management. This shows that there could be a problem with fund allocation in the constituency. The overall mean response of 3.58 implied that the sampled respondents were in agreement on most of the statement regarding project financing while a standard deviation of 1.19 denoted that there was some variation the response on the statement on project financing from project manager/contractors point of view.

Table 3. Project Financing - NG-CDF Committee

\begin{tabular}{lcccc}
\hline Project Financing & Modal class & Median & Mean & STD \\
\hline Accountability and transparency & 4 & 4 & 3.80 & 1.14 \\
Auditing process & 4 & 4 & 4.10 & 0.99 \\
Timely disbursement & 4 & 4 & 3.60 & 0.84 \\
Funds allocation & 4 & 4 & 3.90 & 0.99 \\
Adequate allocation & 4 & 4 & 4.30 & 0.48 \\
Overall Mean & $\mathbf{4}$ & $\mathbf{4}$ & $\mathbf{3 . 9 4}$ & $\mathbf{0 . 8 9}$ \\
\hline
\end{tabular}

Source: Field Data (2017)

From Table 3, Considering the median as the average, the NG-CDF committee agreed with all the statements on project financing with a median of 4 all through and also supported by a mode of 4 all through. The means for all the variables are also all above 3.5 with very low standard deviations. This shows that on average, the committee are in agreement that, there is accountability and transparency in the use of CDF fund for the management of projects, there is satisfactory auditing process of $\mathrm{NG}-\mathrm{CDF}$ projects, there is timely disbursement of funds to the identified projects which have enhanced project management, there is sufficient funds allocated for various aspects of CDF projects which has resulted to effective management of CDF and that CDF funds are adequately allocated to the identified projects which have enhanced project management.

From interviews and focus group discussions, it was revealed that project financing is one of the important determinants of successful CDF project management. Funds are needed in various aspects of projects not only for project itself but for monitoring and evaluation which ensure that the project is implemented according to set rules and regulations. However, it was also revealed that there is inadequate allocation of financial results to project contractors which leaves with no options of facilitating Monitoring and Evaluation (M\&E). The CDF Acts and other regulatory framework put a lot of emphasize on the actual management of funds allocated to CDF funded projects but they are silent on allocations that ensure the 
projects are effectively managed. The FDGs also revealed that untimely disbursement of funds has delayed completion of the projects in Kasipul Constituency. According to beneficiaries, some projects take unnecessary long time. On the other hand, delay in completion of projects have profound effect on the beneficiaries who are forced to wait for long time before benefitting from a project which was commissioned more than three years ago. This scenario affects mostly schools and health projects as citizens are forced to look for alternative which in some cases is usually expensive negating the objective of CDF in poverty alleviation.

\subsection{Test of Hypotheses}

The study further presents Structural Equation Modeling (SEM) in the hypothesis testing. The SEM is an extension of the general linear model and allows researchers to test more than one regression equation simultaneously. The structural model characterizes the relationships between the constructs or the latent variables and defines those latent variables that indirectly or directly cause alterations in the values of other latent variables in the model (Byrne, 2013). SEM allows us to examine the indirect relationships between variables, an approach missing in previous studies. Under SEM, both the measurement model and the confirmatory structural models were assessed.

The measurement model is concerned with the measurement of the latent variables and their indicators. Factor analysis was used for dimension reductions to explore the underlying factors and unidimensionality of each construct (Leech, Barrett and Morgan, 2011). The factor analysis results showed that all indicators of the 2 latent variables effective project management and project financing belonged to their relative latent constructs as shown in table 4 . All the indicators had loadings above 0.4 on the constructs. The table also shows the assessment of validity and reliability of the measurements.

Table 4. Measurement model summary

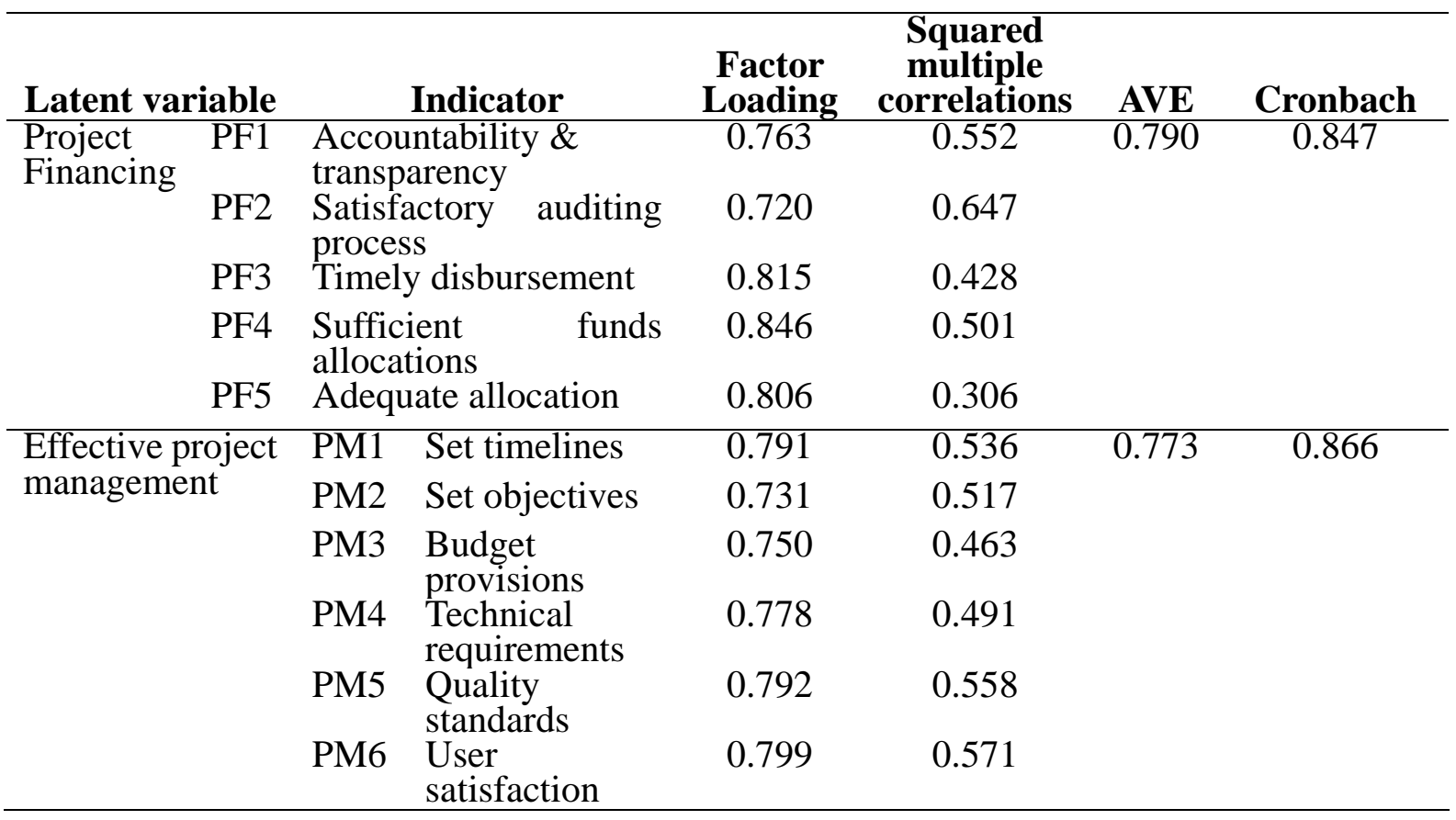


Each latent variable showed reliability as shown by the Cronbach alpha statistics used to examine internal consistency. All the 2 latent variables in study had Cronbach alpha statistics greater than the 0.7 Threshold. To assess construct validity, both convergent and discriminant validity of the data were examined (Fornell \& Larcker, 1981). The average variances extracted for each of the 2 latent constructs were above 0.5 implying convergent validity. The average variances extracted were also all found to be larger than the squared multiple correlations implying discriminant validity.

Table 4. Correlations matrix

\begin{tabular}{|c|c|c|c|}
\hline & & Project financing & $\begin{array}{l}\text { Effective project } \\
\text { management }\end{array}$ \\
\hline Project financing & & 1 & \\
\hline 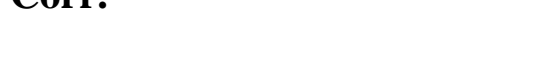 & & 0.000 & \\
\hline $\begin{array}{l}\text { Sig. } \\
\text { Effective project management } \\
\text { Sig. }\end{array}$ & Corr. & $\begin{array}{l}.715^{* *} \\
0.000\end{array}$ & $\begin{array}{l}1 \\
0.000\end{array}$ \\
\hline
\end{tabular}

The results in table 4 indicated that project financing has a significant relationship with dependent variable (Effectiveness of CDF project management). The relationship between project financing and effective project management was strong $(\mathrm{r}=0.715$, $\mathrm{p}$-value $=<0.05)$. This shows a significant relationship between project financing and effective project management.

A SEM was fitted and from the goodness of fit of the model, it was found that model fitted the data well given that the chi-square statistic with $\mathrm{p}$ value of 0.000 . This was also confirmed by other criteria for model fitness such as Root Mean Squared Error of approximation which was found to be 0.067 which is adequately below the desired threshold of 0.08 . The model also met the other fit indices requirements normed fit index (NFI), comparative fit index (CFI), goodness of fit index (GFI) and parsimony fitness PGFI and PNFI as shown in table 5.

Table 5. Goodness of fit tests

\begin{tabular}{|c|c|c|c|c|}
\hline Index & \multicolumn{2}{|c|}{ Model } & Desired (good fit) threshold & \multirow{2}{*}{$\frac{\text { Status }}{\text { Good fit }}$} \\
\hline Chi-square & $\begin{array}{l}\text { Statistic } \\
\text { P-value }\end{array}$ & $\begin{array}{r}125.140 \\
0.000\end{array}$ & p-value $<0.05$ & \\
\hline NFI & & 0.951 & $\geq 0.9$ & Good fit \\
\hline CFI & & 0.962 & $\geq 0.9$ & Good fit \\
\hline GFI & & 0.948 & $\geq 0.9$ & Good fit \\
\hline SRMR & & 0.040 & $<0.08$ & Good fit \\
\hline RMSEA & & 0.067 & $\leq 0.08$ & Good fit \\
\hline PGFI & & 0.536 & $\geq 0.5$ & Good fit \\
\hline PNFI & 0.542 & & $\geq 0.5$ & Good fit \\
\hline
\end{tabular}

The SEM fitted show the extent of influence of project financing on effective NG-CDF project management. Table 6 shows the regression coefficient estimated weights of the SEM fitted. The path coefficients of the estimated model were tested for significance to establish the significance of the causal relationships between the determinants and effective management of projects. The critical ratio of the fitted estimates follows a standard normal 
distribution thus considers 1.96 as the critical point at $5 \%$ level of significance.

Table 6. Regression Weights

\begin{tabular}{|c|c|c|c|c|c|c|}
\hline \multicolumn{3}{|c|}{ Path } & Estimate & S.E. & C.R. & $\mathbf{P}$ \\
\hline PM & $<---$ & PF & 1.436 & .145 & 9.919 & $* * *$ \\
\hline PF5 & $<---$ & PF & 1.000 & & & \\
\hline PF4 & $<---$ & PF & 1.320 & .097 & 13.546 & $* * *$ \\
\hline PF3 & $<---$ & PF & 1.247 & .101 & 12.365 & $* * *$ \\
\hline PF2 & $<---$ & PF & 1.729 & .163 & 10.630 & $* * *$ \\
\hline PF1 & $<--$ & $\mathrm{PF}$ & 1.389 & .137 & 10.164 & $* * *$ \\
\hline PM1 & $<---$ & PM & 1.000 & & & \\
\hline PM2 & $<---$ & PM & .846 & .063 & 13.392 & $* * *$ \\
\hline PM3 & $<---$ & PM & .829 & .068 & 12.220 & $* * *$ \\
\hline PM4 & $<---$ & PM & .887 & .069 & 12.890 & $* * *$ \\
\hline PM5 & $<---$ & PM & 972 & .062 & 15.670 & $* * *$ \\
\hline PM6 & $<---$ & PM & 1.047 & .074 & 14.221 & $* * *$ \\
\hline
\end{tabular}

The critical ratios for the estimate of project financing (PF) were found to be 9.919 that have an absolute value greater than 1.96 implying significance at 5\%. This implies that project financing improved the effective management of NG-CDF funded projects. Figure 1, shows details on the paths with respective coefficients.

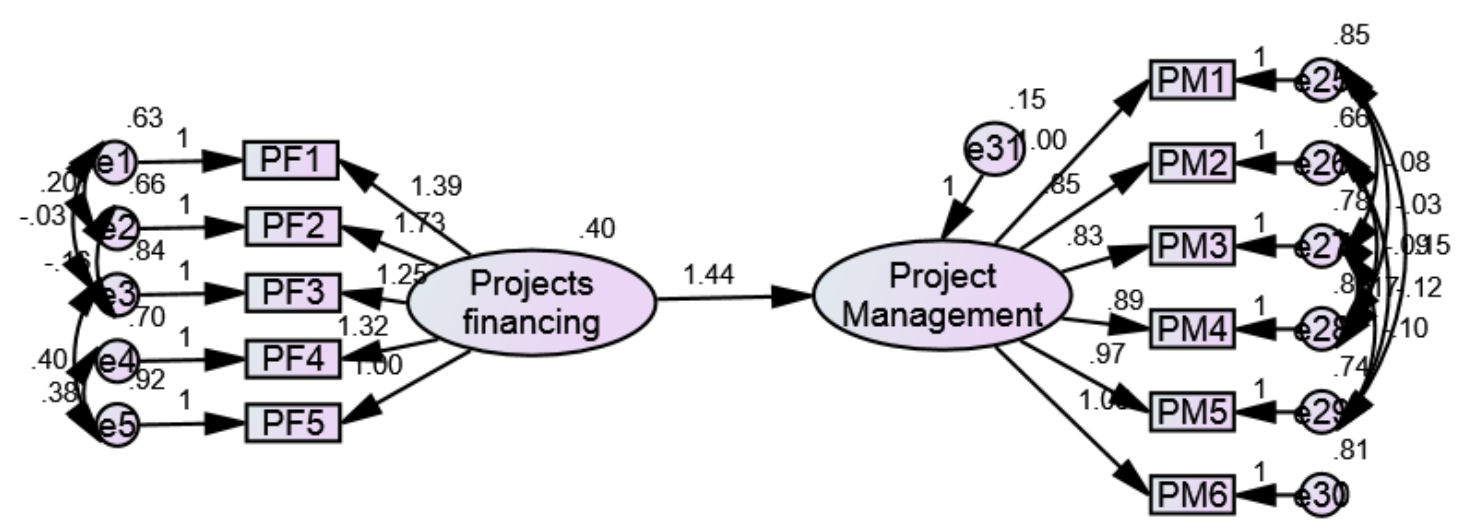

Figure 1. Path Analysis; Project financing and Effectiveness of NG-CDF funded projects

From the estimates in Table 5 and Figure 1, it was revealed that increasing financing of the projects by a unit significantly raises the effectiveness of NG-CDF project management by 1.436 units. This implies that the null hypothesis of no significant effect is rejected. Based on individual construct that measured project financing, it can be deduced that accountability and transparency of CDF project fund usage, timely disbursement of funds and to identify project and adequate allocation of funds was found to influence the effectiveness of CDF project management.

\section{Conclusion and Recommendations}

The main objective of the study was to investigate the role of project financing on effective NG - CDF project management in Kasipul Constituency, Homa bay County, Kenya. To achieve the set objective, hypothesis was formulated based on a review of literature. The hypothesis was subjected to observed index matrix analysis and path analysis. Based on the 
findings of the model on effective NG - CDF project management, the study came up with the following conclusions; that adequacy in allocation to projects, timely disbursement of the funds, auditing process, transparency and accountability positively and significantly influenced quality standards and improved user satisfaction levels concluding that there is need to strengthen a project financing framework at the constituency level.

The study recommends that there should be a clear financing framework that is focused to allocation of funds for approved projects with clear implementation plans to achieve success in $\mathrm{CDF}$ project management. At the moment, the CDF Acts stipulate a minimum of $2.5 \%$ of National budget to be allocated to CDF. The act can be amended so that the amount allocated to each constituency is increased to at least $7.5 \%$ of the national budget to cover all aspects of identified projects at the constituency. Further, there has been delay in disbursement of fund from national government which spill over to constituency. This delay can be overcome by enacting a law that would make it mandatory for national government to disburse at particular dates in a given financial year thereby making the constituency to make proper arrangement on project financing with their contractors. A clear working mechanisms need to be established between county governments and NG-CDF managers to subsidize some of the projects or even corroborate in implementing projects at the constituency level since the county governments in Kenya have more ways of raising funds. Lastly, the CDF committee should adopt a project financing model which would allow full allocation of project instead of funding several projects at once. They would reduce overhead cost both of CDF committee and for the contractors while at the same time delivering completed project within shortest time possible

\section{References}

Amponsah, V. (2012). An Investigation into the Effect of Management Development on Performance: A Case Study of Offinso Municipal Assembly. Kwame Nkrumah University of Science and Technology. Accra

Babbie, E. R. (2004). The Practice of Social Research. Belmont C. A.: Wadsworth.

Bagaka, O. (2008). Fiscal decentralization in Kenya and the growth of government: The Constituency Development Fund. Illinois: Northern Illinois University.

Barney, J. B. (2007). Gaining and sustaining competitive advantage (3rd ed.). Upper Saddle River, NJ: Pearson Education.

Creswell. (2003). Research Design; Qualitative, Quantitative, and Mixed Methods Approaches. Second edition. University of Nebraska, Lincoln.

Dooley, D. (2007). Social Research Methods. Prentice Hall. New Delhi:

Elbannan, M. A. (2009). Quality of internal control over financial reporting, corporate governance and credit ratings. International Journal of Disclosure and Governance, 6(2), 127-149. https://doi.org/10.1057/jdg.2008.32

Government of Kenya (2003). Constituencies Development Fund Act 2003. Retrieved 9th August 2012. 
Government of Kenya (2015). Kenya Gazette Supplement Acts, 2015. Government Printer, Nairobi

Government of Kenya. (2005). Public Procurement and Disposal Act, 2005. Nairobi: Government Printer.

Haseeb, M., Xinhai-Lu, A. B., Maloof-ud-Dyian, A., \& Rabbani, W. (2011). Problems of Projects And Effects of Delays in The Construction Industry of Pakistan. Australian Journal of Business and Management Research, 1(5), 41-50.

Isaac, S., \& Michael, W. B. (1995). Handbook in Research and Evaluation. EdITS. San Diego:

Kenya National Bureau of Statistics and Society for international development (2013). Exploring Kenya Inequality. Nairobi Kenya.

Khalied, H., \& Amr, K. (2009).Validity of Feasibility Studies for Infrastructure Construction Projects. Jordan Journal of Civil Engineering, 3(1), 66-77.

Kline, P. (1999). The handbook of psychological testing (2nd ed). Routledge, London

Loo, R. (2002). Working towards best practices in project management: A Canadian study. International Journal of Project Management, 20, 93-8. https://doi.org/10.1016/S0263-7863(00)00042-9

Mapesa, B. M., \&Kibua, T. N. (2006). An assessment of the management and utilization of the constituency development fund in Kenya", Discussion Paper No. 076/2006, Institute of Policy Analysis and Research, Nairobi.

Mensah, J., Oppong, J. R., \& Schmidt, C. M. (2010). Ghana's National Health Insurance Scheme in the Context of the Health MDGs: An Empirical Evaluation Using Propensity Score Matching. Health Economics, 19, 95-106. https://doi.org/10.1002/hec.1633

Mugenda, O. M., \&Mugenda, A. G. (2003). Research Methods. Quantitative and qualitative approaches. Nairobi. Acts Press.

Mwangi, S. (2005). Efficiency and Efficacy of Kenya's Constituency Development Fund: Theory and Evidence. Economics Working Papers paper.200542 on www.digitalcommons.ucon.edu accessed on 18th March 2014.

Nassiuma, D. (2000). Survey sampling: Theory and methods. Egerton University Press. Njoro, Kenya

National Taxpayers Association March. (2012). Citizens CDF Report Card for Machakos Town Constituency. NTA, Nairobi

Ochieng, E. (2014). The influence of devolved funds on implementation of community based development project in Karachuonyo constituency, University of Nairobi.

Orodho, J. A. (2004). Element of Education and Social Science Research Methods. Masola Publishers. Nairobi: 


\section{Macrothink}

Journal of Public Administration and Governance ISSN 2161-7104 2018, Vol. 8, No. 3

Owuor, F., Chepkuto, C., Tubey, R., \& Kuto, Y. (2012). Effectiveness of monitoring and evaluation of CDF projects in Kenya. A case of Ainamoi Constituency. International Journal of Arts and Commerce, 1(6).

PPOA. (2007). Assessment of the Procurement System in Kenya Report. A report by Public Procurement Oversight Authority, Nairobi.

Pretorius, C. (2007). Design and Management of Public Financial Management Reforms. (Unpublished background paper for the Afritac retreat on the Design and Management of Public Financial Management Reforms). Publisher, 2nd Ed.

Sambasivan, M., \& Soon, Y. W. (2007). Causes and effects of delays in Malaysian construction industry, International Journal of Project Management, 25(5), 517-526. https://doi.org/10.1016/j.ijproman.2006.11.007

Sekaran, U. (2003). Research Methods for Business: A Skill Building Approach.(4 ${ }^{\text {th }}$ edn.) John Wiley \& Sons, Inc. New York.

Tounde, A. (2012). Factors influencing implementation of community based poultry project in guinea Bissau: local approaches to community developments, Bissau publishing press.

Waal, A. A. de (2004). Stimulating performance-driven behavior to obtain better results, International Journal of Productivity and Performance Management, July Strunk.

\section{Copyright Disclaimer}

Copyright for this article is retained by the author(s), with first publication rights granted to the journal.

This is an open-access article distributed under the terms and conditions of the Creative Commons Attribution license (http://creativecommons.org/licenses/by/4.0/). 